일반논문-10-15-3-01

$$
\begin{aligned}
& \text { 주기적 I-프레임 구조의 H.264 부호화 동영상을 위한 플리커링 측정 } \\
& \text { 알고리즘 } \\
& \text { 임 종 민, }{ }^{\mathrm{a}} \text {, 강 동 욱, } \text {, 정 경 훈 }{ }^{\mathrm{a}}
\end{aligned}
$$

\title{
Measurement of Flickering Artifact for H.264 with Periodic I-Frame Structure
}

\author{
Jong-Min Lim ${ }^{\text {a) }}$, Dong-Wook Kang ${ }^{\text {a)}}$, and Kyeong-Hoon Jung ${ }^{\text {a) }}$ \\ 요 약
}

멀티미디어 동영상의 부호화 알고리즘은 기본적으로 손실 부호화 방식이기 때문에 압축된 동영상에는 불가피하게 화질의 열화 요인 이 포함된다. 플리커링(flickering)은 시간 영역에서의 대표적인 부호화 잡음으로서 부호화 비트율을 제어하기 위해서 양자화 파라미터 를 변동하는 과정에서 연속되는 프레임들의 화질이 일정치 않음으로 인해 발생하는 현상이다. 본 논문에서는 주기적으로 I 프레임이 삽입되는 GOP(Group of Picture) 구조를 사용하는 환경에서 동영상의 시공간적 특성에 따른 플리커링 현상을 분석하고 FR(Full Reference) 기반의 플리커링 측정 알고리듬을 제안한다. 플리커링 현상은 중간 화질 영역에서 중요하게 고려해야 할 부호화 잡음이며, 프레임 내의 세밀함의 정도, 움직임의 정도, 객체의 크기, 카메라 파라미터 등에 영향을 받음을 알 수 있었다. 제안한 플리커링 측정 알고리즘은 다양한 특성의 영상에 대해 인간의 시각특성과 부합되는 우수한 결과를 보였다.

\begin{abstract}
Most of multimedia video coding algorithms are lossy schemes and several kinds of spatial and temporal artifacts are inevitable. Flickering, which is the most typical coding artifact in time domain, is mainly due to fact that the quality of coded sequence fluctuates as the quantization parameter is adjusted for rate control. In this paper, we analyzed the effect of quality variation according to the characteristics of video sequence when the I-frames are periodically inserted. And we proposed the FR(Full Reference)-based assessment algorithm to measure the amount of flickering artifacts in the coded video. It is discovered that the flickering becomes critical when the level of quality is intermediate and is affected by the amount of detail or movement, the size of object, and camera parameters. The proposed measurement algorithm shows is well consistent with HVS(Human Visual System).
\end{abstract}

Keyword: Flickering, Quality Assessment, H.264

a) 국민대학교 전자공학부

School of Electrical Engineering, Kookmin University

† 교신저자 : 정경훈(khjung@kookmin.ac.kr)

※ 본 연구는 2009 년도 국민대학교 교내연구비를 지원받아 수행되었음.

- 접수일(2009년12월17일),수정일(1차:2010년3월4일,2차:4월15일),게재확정일(2 010년4월15일)

\section{I. 서 론}

IPTV(Internet Protocol TV) 및 DMB(Digital Multimedia Broadcasting) 등 멀티미디어 동영상 서비스의 활성화를 위 해서는 QoS(Quality of Service) 또는 QoE(Quality of Ex- 
perience) 품질과 관련된 다양한 요소들을 명확하게 정의하 고 이를 측정하고 평가하는 기술의 개발이 요구된다. 이러 한 기술은 직접적으로는 서비스 품질에 문제가 발생한 경 우 이의 원인을 파악하고 대처하기 위해서 필요하며, 비즈 니스 측면에서는 서비스 사업자, 네트워크 사업자, 그리고 최종 이용자 사이에서 제공되는 멀티미디어 동영상의 품질 이 SLA(Service Level Agreement)에 의해서 정해진 수준 을 만족하는 지에 대한 평가 결과를 모니터하기 위해서도 요구된다. ${ }^{[1]}$ 동영상의 품질 평가 기준으로서 PSNR(Peakto-peak Signal to Noise Ratio)이 일반적으로 사용되기는 하지만 이 값은 사람이 인지하는 화질 평가와는 상당한 차 이를 보이기 때문에 이를 화질 평가의 절대적인 기준으로 생각하기에 곤란하다. 이에 따라 국제적인 표준화 단체인 ITU(International Telecommunication Union)와 VQEG (Video Quality Expert)을 중심으로 블록형, 뭉개짐, 물결형 잡음 등과 같은 공간적 열화와 거짓 에지, 움직임 불일치 등의 시간적 열화에 대해서 멀티미디어 동영상의 객관적 화질 측정 방법에 대한 연구가 진행 중이다.

여러 부호화 잡음 가운데 플리커링(flickering) 현상은 시 간적 영역에서 발생하는 대표적인 잡음으로서 부호화된 동 영상내에 존재하는 플리커링의 정도를 측정하고 이의 영향 을 줄이기 위한 연구들이 진행되고 있다. 기존의 연구를 크 게 구분하면 전체 시퀀스를 I 즉 인트라(intra) 프레임 기반 으로 부호화한 경우에 대한 방법과 주기적으로 I 프레임을 삽입하는 구조로 부호화한 경우에 대한 방법으로 나뉜다.

전자의 방법 가운데, Becker 및 Leontaris 등은 플리커링 을 측정하기 위해서 웨이브렛(wavelet)에 기반을 둔 방법을 사용하였으며 ${ }^{[2-3]}$, Fan은 동영상 시퀀스 전체가 H.264 인트 라 모드로 부호화된 경우에 연속적인 I 프레임들 사이에서 인트라 예측 모드가 사용될 때 발생하는 차이를 기준으로 플리커링을 측정하는 방법을 사용하였다 ${ }^{[4]}$. 후자의 방법으 로서, Sakaida 및 Chun 등은 I 프레임이 주기적으로 삽입된 시퀀스에서 I 프레임에서 발생되는 플리커링 현상을 줄이 기 위해서 양자화의 크기, 인트라 예측 차이, 인터 모드에서 의 스킵 모드 등의 조건을 $\mathrm{RD}$ 비용함수(Rate- Distortion cost function)에 추가하는 방법을 제안하였다 ${ }^{[5-6]}$. 그리고 Chono 등은 $\mathrm{DQ}$ (Detented Quantization) 스위칭 방법을 제
안하였는데, 이 방법에서는 현재 인트라 $\mathrm{MB}$ (Macroblock) 의 부호화 과정에서 DCT 계수를 양자화 함에 있어서 원본 영상을 사용하는 경우에 발생하는 계수와 P 또는 B 프레임 을 참조하는 경우에 발생하는 계수를 비교하여 둘 중 하나 를 선택함으로써 플리커링 현상을 감소시킨다 ${ }^{[7]}$. 한편 Yang 등은 H.264 방식에서 주기적으로 I 프레임이 삽입된 $\mathrm{GOP}$ (Group of Picture) 구조로 부호화할 때, I 프레임과 이 전 프레임 사이의 차이로서 플리커링을 판단하고 이를 제 거하는 방법을 제안하였다 ${ }^{[8]}$.

이들 기존의 연구에서는 I 프레임에 존재하는 플리커링 현상이 사람의 인지적 화질에 큰 영향을 미친다는 사실에 주목하고 이를 줄이기 위한 다양한 방법을 제안하였지만, 실제로 사람이 시각적으로 경험하는 플리커링 현상 자체에 대한 분석은 상대적으로 미흡하였으며, 더군다나 플리커링 을 정의하고 측정하기 위한 공통의 알고리즘이 없기 때문 에 플리커링 제거 기법들의 성능 평가가 쉽지 않았다. 본 논문에서는 주기적으로 I 프레임이 삽입되는 GOP(Group of Picture) 구조를 전제로, 다양한 멀티미디어 동영상의 시 공간적 특성이 플리커링 현상에 미치는 영향을 분석하고, 플리커링 평가를 위한 객관적인 도구로서 FR(Full Reference) 기반의 측정 알고리듬을 제안한다.

\section{II. 플리커링 현상의 분석}

\section{1. 플리커링의 발생 원인}

플리커링 현상은 프레임과 프레임 사이에 존재하는 화질 의 시간적인 변동이 시각적으로 인식되면서 발생한다. 일 단 부호화 과정에서 프레임율(frame rate)이 너무 낮은 경우 에는 인접한 프레임 사이에서 움직임이 자연스럽지 않고 불연속적으로 튀는 현상이 발생할 수 있다. 그렇지만 프레 임율이 충분히 높다고 하더라도 일반적인 멀티미디어 동영 상 시퀀스의 부호화 과정에서는 주기적으로 I 프레임이 삽 입되고 발생 비트율(bit rate)을 조절하기 위해서 양자화 파 라미터를 변경하기 때문에 프레임 마다 할당되는 데이터 량이 변동하게 된다. 이는 결국 부호화된 영상의 품질이 시 


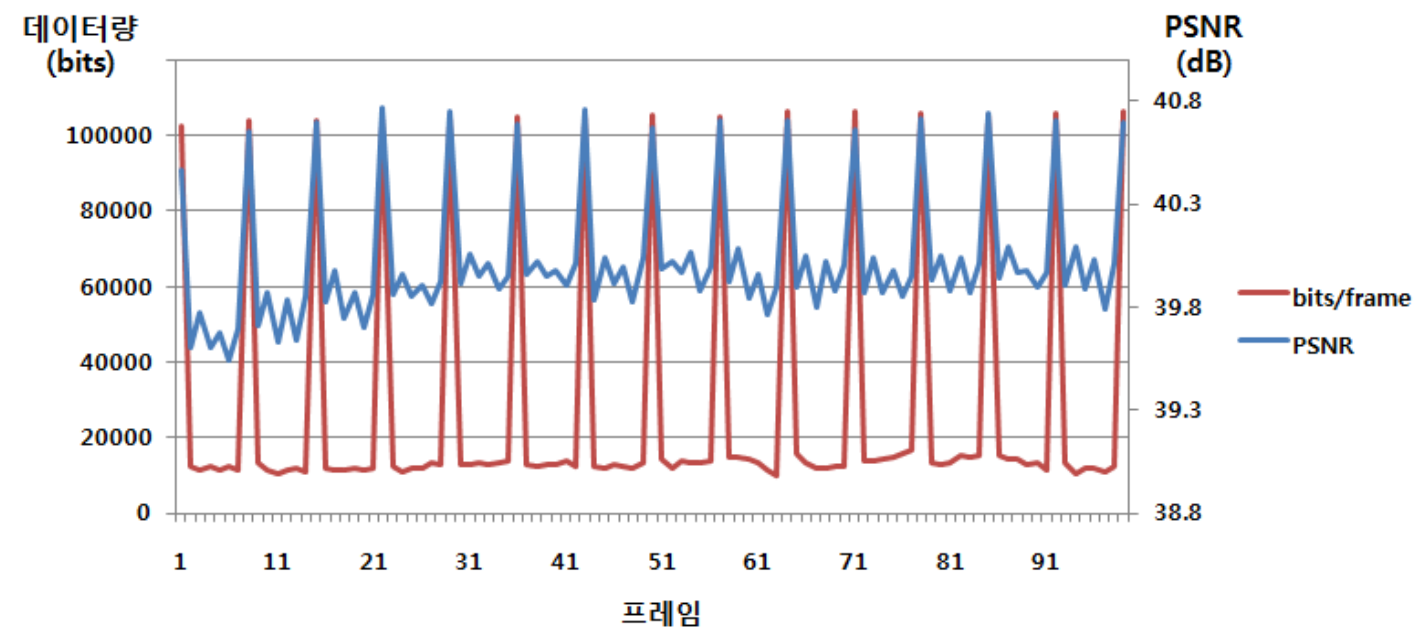

그림 1. GOP 구조에서의 프레임당 비트율과 PSNR

Fig. 1. Bitrate and PSNR in GOP structure

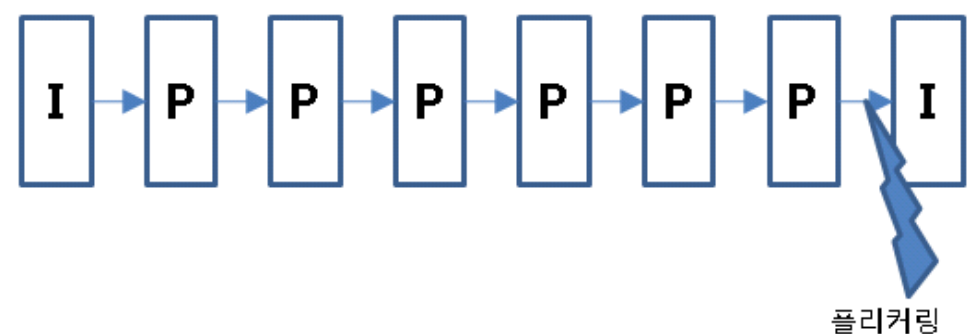

그림 2. 주기적인 I 프레임 구조에서 플리커링 발생

플리커림

Fig. 2. Flickering artifact in periodically inserted I frame

간적으로 일정하게 유지되지 않다는 것을 의미한다.

주기적으로 I 프레임이 삽입되는 $\mathrm{GOP}$ 구조를 사용하여 멀티미디어 동영상 시퀀스를 부호화하는 과정에서 나타나 는 발생 비트율과 PSNR의 전형적인 모습을 그림 1에서 나 타내었다. 발생하는 비트율과 PSNR이 동시에 그리고 주기 적으로 증가함을 볼 수 있는데, I 프레임 부호화를 위해서는 움직임 보상 예측 기법이 사용되지 않기 때문에 I 프레임이 등장할 때마다 데이터량이 급격하게 늘어나고 화질이 향상 되는 것이다. 비록 PSNR이라는 지표가 사람의 인지적 화 질을 그대로 반영하지 않기는 하지만 화질이 등락한다는 것을 확인할 수 있다.

이러한 화질의 변동 과정에서 문제가 되는 것은 새로운 $\mathrm{GOP}$ 가 시작되면서 I 프레임이 삽입되는 순간이다. GOP 내부의 P(Predictive) 또는 B(Bi-predictive) 프레임의 경우
에는 절대적인 화질이 I 프레임에 비해 낮지만 이전 프레임 으로 부터의 화질의 변동은 크지 않기 때문에 플리커링 현 상은 거의 눈에 띄지 않는다. 하지만 새로 I 프레임이 삽입 되면 화질이 갑자기 향상되면서 시간적인 변동이 나타나서 오히려 사람의 시각에 거슬리게 된다. 따라서 플리커링의 측면에서는 전체 시퀀스의 평균 화질이 낮더라도 프레임 사이의 화질의 변동이 없는 경우가 평균이 높고 변동이 심 한 경우 보다 더 바람직하다고 할 수 있다.

\section{2. 동영상 시퀀스의 특성에 따른 플리커링 현상}

한편 시각적으로 인지되는 플리커링 현상은 부호화되는 동영상 시퀀스의 시공간적인 특성에 따라서도 많은 영향을 
받는다. 이를 살펴보기 위해서 한국방송공사(KBS)와 한국 통신 $(\mathrm{KT})$ 에서 서비스되는 다양한 종류의 동영상 시퀀스를 대상으로 100 프레임씩 잘라서 실험을 실시하였다. 실험 영 상들을 그림 3 에 나타내었는데, 동영상의 형식은 $\mathrm{YCbCr}$
4:2:0이며 해상도는 $320 \times 240$ 이다. 장르별로는 뉴스, 일기 예보, 드라마, 게임, 스포츠, 다큐멘터리 등이 포함되었다. 다음의 표 1 에서는 각 동영상 시퀀스가 가지고 있는 특성 을 공간특성, 객체크기, 시간특성, 그리고 카메라 움직임 파

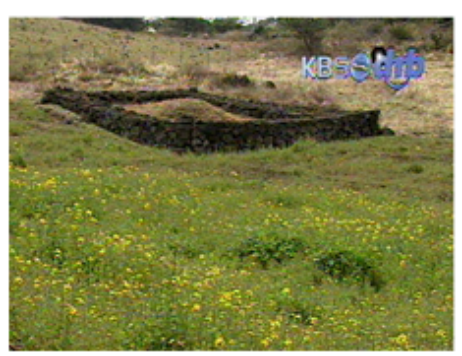

(a) field

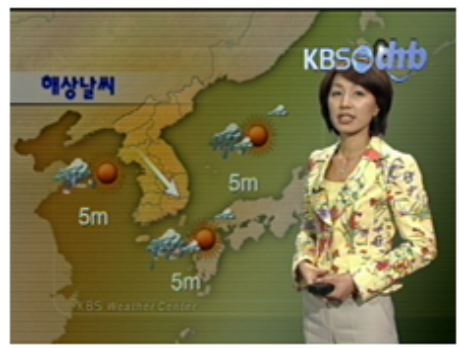

(d) weather

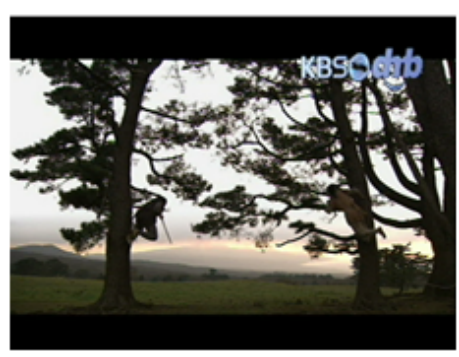

(g) drama

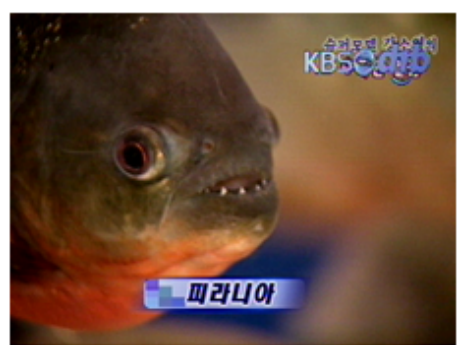

(j) fish

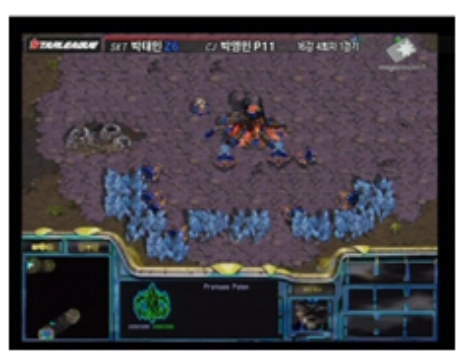

(b) game

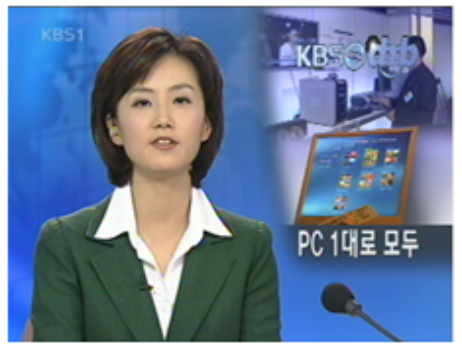

(e) news

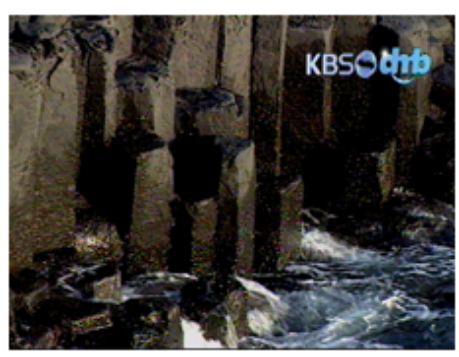

(h) wave

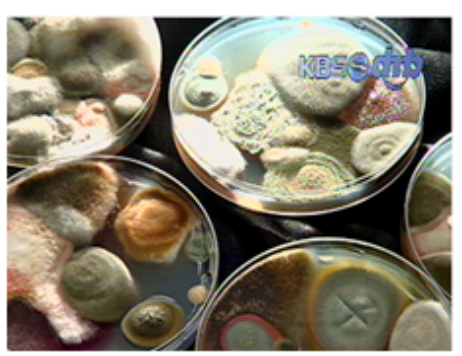

(c) mold

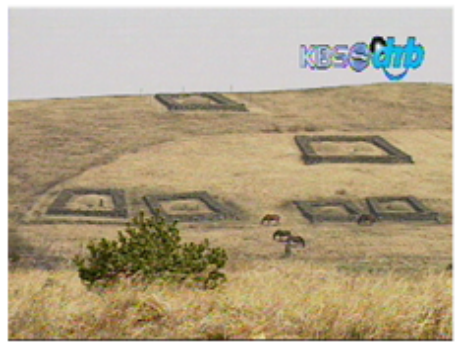

(f) plain

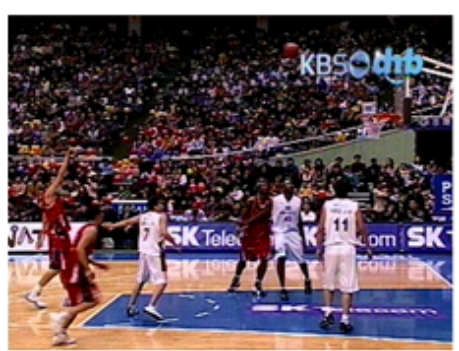

(i) sport

그림 3. 실험 영상

Fig. 3. Test sequences 
표 1. 실험영상에 대한 특성 분석

Table 1. Characteristics of test sequences

\begin{tabular}{|c|c|c|c|c|c|}
\hline 동영상 & 프레임번호 & 공간특성 & 객체크기 & 시간특성 & 카메라 움직임 \\
\hline field & $1-100$ & 세밀 & 없음 & 전체적, 불규칙적, 많은움직임 & 없음 \\
\hline \multirow{2}{*}{ game } & $1-100$ & 세밀 & 작음 & 부분적, 불규칙적, 중간움직임 & 없음 \\
\hline \multirow{2}{*}{ mold } & $1-26$ & 세밀 & 보통 & 정지 & 없음 \\
\cline { 2 - 7 } & $27-85$ & 보통 & 큼 & 정지 & 없음 \\
\cline { 2 - 7 } & $86-100$ & 보통 & 큼 & 정지 & 없음 \\
\hline \multirow{2}{*}{ weather } & $1-100$ & 단순 & 보통 & 중간움직임 & 없음 \\
\hline \multirow{2}{*}{ news } & $1-100$ & 단순 & 보통 & 적은움직임 & panning \\
\hline \multirow{2}{*}{ plain } & $1-100$ & 세밀 & 없음 & 많은움직임 & zoom-in \\
\hline \multirow{2}{*}{ drama } & $1-56$ & 세밀 & 보통 & 많은움직임 & zoom-in \\
\cline { 2 - 7 } & $57-100$ & 보통 & 없음 & 중간움직임 \\
\hline \multirow{2}{*}{ wave } & $1-100$ & 혼합 & 큼 & 부분적, 불규칙적, 많은움직임 & panning, zoom-in \\
\hline \multirow{2}{*}{ sport } & $1-56$ & 세밀 & 보통 & 전체적, 불규칙적, 많은움직임 & panning \\
\cline { 2 - 7 } & $57-100$ & 세밀 & 큼 & 부분적, 불규칙적, 중간움직임 & 없음 \\
\hline \multirow{2}{*}{ fish } & $1-100$ & 세밀 & 큼 & 부분적, 불규칙적, 많은움직임 & \\
\hline
\end{tabular}

라미터 등 네 가지 측면에서 정리한 결과를 나타내었다. 실 험 영상 가운데 시퀀스 도중에 장면 전환(scene change)이 존재하는 경우에는 장면 단위로 특성을 분류하였다.

동영상 시퀀스의 특성에 따른 플리커링 현상을 분석하 기 위해 H.264 JM16.0 ${ }^{[9]}$ 을 사용하여 부호화하였으며, 양 자화 파라미터 $\mathrm{QP}$ 의 값을 15 에서부터 45 까지 변화시켜 가면서 높은 품질의 영상에서부터 낮은 품질의 영상까지 이르기까지 넓은 화질 범위를 관찰하였다. 이 때 $\mathrm{GOP}$ 크 기는 7로 설정하였으며, $\mathrm{B}$ 프레임은 사용하지 않았고, 비 트율 제어 알고리즘으로는 CBR(Constant BitRate)을 사용 하였다. 그리고 화질의 평가를 위해 Visual Studio MFC Application으로 개발한 YUV 플레이어를 이용하여 각 시 퀀스의 원본 영상과 부호화하여 처리한 영상을 동시에 비 교하였다. 그리고 플리커링의 평가는 주관적 화질 평가 방 법인 ITU-T의 P.910 ACR(Absolute Category Rating) ${ }^{[10]}$ 에 따라 진행하였다.

실험을 통해 발견한 가장 기본적인 관찰 결과는 동영상 의 특성과 상관없이 대부분의 영상에서 QP 값이 25 32 사 이의 범위에서 플리커링이 나타나며 QP 값이 너무 높거나 너무 낮으면 플리커링 현상이 두드러지지 않는다는 사실이
다. 이 이유는 QP 값이 충분히 낮아서 부호화 영상의 품질 이 일정 수준을 넘게 되면 비록 화질의 사소한 변동이 있더 라도 시각적으로 인지되기 힘들고, 반대로 $\mathrm{QP}$ 값이 너무 높 아서 양자화의 크기가 커지게 되면 화질의 변동이 있기는 하지만 플리커링 보다는 블록화, 뭉게짐, 물결형 잡음 등 다른 화질 열화 요인이 시각적으로 훨씬 많은 영향을 미치 기 때문으로 판단된다.

또한 플리커링은 부호화의 대상이 되는 동영상의 공간적 특성 및 시간적 특성에 따라 마스킹(masking)되는 효과가 있다. 예를 들어 배경은 거의 움직이지 않고 객체만 이동하 는 경우에는 움직임이 있는 객체보다는 배경 영역에서 플 리커링이 더 확실하게 발견된다. 이는 사람의 시각 특성이 동적인 움직임에 훨씬 더 민감하기 때문에 움직임이 있는 영역에서의 화질의 변화를 쉽게 인지하지 못하기 때문이다. 반면에 영상 시퀀스에 움직임이 거의 없는 경우에는 다큐 멘터리와 같이 공간적으로 세밀한 영상에서 플리커링 현상 이 시각적으로 인식될 가능성이 다소 증가한다. 세밀한 영 역일수록 화질의 작은 변동이 공간적으로 복잡한 변화를 일으키기 쉽기 때문이다.

그리고 panning, zooming, tilting 등과 같이 카메라 제어 
파라미터가 있으면 동영상이 움직임 성분이 있는 경우와 거의 유사한 영향을 미친다. 즉 카메라가 움직이는 여러 가 지 효과가 복합적으로 포함된 경우에는 움직임의 복잡도가 증가하기 때문에 동영상의 다른 특성과 관계없이 플리커링 현상이 마스킹 되는 경향이 있다.

실험에서는 sport와 fish를 제외한 나머지 동영상에 대해 서 양자화 파라미터 값이 증가함에 따라서 대부분 플리커 링 현상이 발생하였다. 플리커링이 나타나지 않은 두 동영 상의 경우는 공간적으로는 화면에 존재하는 객체의 크기가 크고 시간적으로는 객체의 움직임이 활발한 특성을 가지고 있다. 따라서 객체 영역에서는 움직임으로 인한 마스킹 효 과 때문에 플리커링을 관찰하기 힘들고, 배경의 경우도 크 기가 큰 객체가 움직이면서 나타났다가 사라지는 영역이 계속 불규칙하게 바뀌기 때문에 화질의 변화가 시각적으로 눈에 띄지 않기 때문이다.

\section{III. 플리커링 측정 알고리즘}

\section{1. 제안 알고리즘의 기본 개념}

팢ㅇㅇ에서의 분석 결과를 통해 플리커링이란 부호화된 동 영상의 절대적인 화질의 차이라기 보다는 화질의 시간적인 변동이라고 정의할 수 있으며 이는 동영상의 시공간적 특

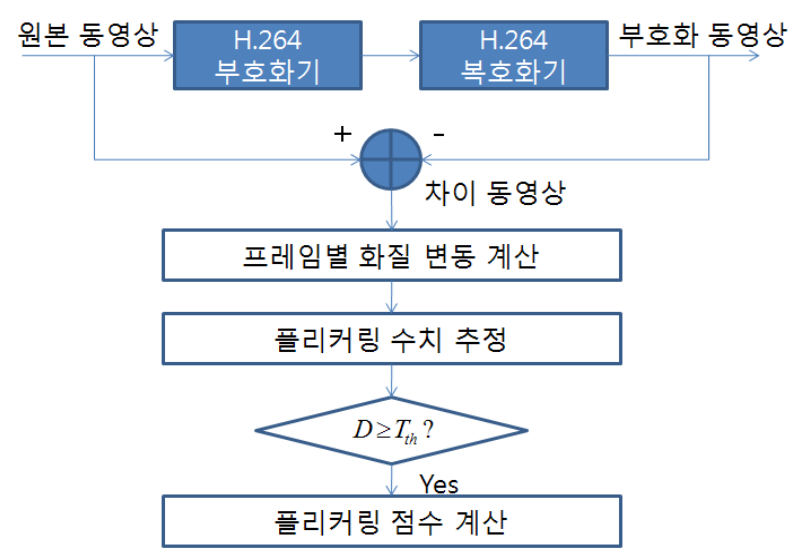

그림 4. 제안 알고리즘 블록도

Fig. 4. Block diagram of proposed algorithm
성에 따라 영향을 받음을 알 수 있다. 여기서는 플리커링을 측정하기 위한 FR 기반의 알고리즘을 제안한다. 제안 알고 리즘의 블록도를 그림 4에 나타내었다.

먼저 원본 동영상의 i-번째 프레임 $f_{\text {ori } i, i}$ 과 부호화된 동영 상의 i-번째 프레임 $f_{r e c, i}$ 이 주어질 때, 이로부터 차이 동영 상 시퀀스의 i-번째 프레임 $f_{r e s, i}$ 을 다음 식(1)과 같이 계산 한다.

$$
f_{\text {res }, i}=f_{\text {ori }, i}-f_{\text {rec }, i}
$$

그리고 차이 동영상 시퀀스에서 인접한 프레임간 차이의 절대값을 취하여 i-번째 프레임의 화질 변동, $v_{i}$ 를 구한다.

$$
v_{i}=\left|f_{\text {res }, i}-f_{\text {res }, i-1}\right|
$$

실제로 플리커링을 측정할 필요가 있는 상황은 $\mathrm{GOP}$ 가 시작하면서 새로 I 프레임이 삽입되는 경우이다. 그리고 이 때 플리커링의 정도는 현재 GOP의 I 프레임 화질 변동이 이전 $\mathrm{GOP}$ 의 P 프레임 및 현재 $\mathrm{GOP}$ 의 $\mathrm{P}$ 프레임의 화질 변동에 비해 얼마나 달라지는 지에 따라 결정된다. $\mathrm{g}$-번째 $\mathrm{GOP}$ 의 I 프레임의 화질 변동을 $v_{g, I}, \mathrm{P}$ 프레임의 화질 변동 의 평균값을 $v_{g, P_{a v g}}$ 라고 할 때, $\mathrm{g}$-번째 $\mathrm{GOP}$ 의 I 프레임의 플리커링 수치, $D_{g, I}$ 는 다음과 같이 계산한다.

$$
D_{g, I}=\left|v_{g, I}-v_{b g r}\right| v_{b g r} \text { where } v_{b g r}=\left(v_{g-1, P_{a v g}}+v_{g, P_{a v g}}\right) / 2
$$

한편 플리커링 현상은 시간적으로 나타나는 잡음이기 때 문에 특정한 한 프레임 보다는 전체 동영상 또는 장면 (scene) 단위에서 판단하는 것이 의미가 있다. 따라서 임의 의 동영상 또는 장면에 포함된 I 프레임들의 $D_{g, l}$ 의 평균값 을 계산하여 이를 해당 동영상 또는 장면의 플리커링 수치 $D_{s c}$ 로 사용한다.

앞서 ㅍㅏㅏㅇ에서 살펴보았듯이, 플리커링 현상이 인지적으 로 의미를 가지기 위해서는 경우는 규칙적인 화질의 변동 이 일정 수준 이상이 되어야 한다. 만일 이 값이 임계값보다 작다면 화질 변동이 미미하기 때문에 사람이 이를 인지하 지 못하거나 화질이 변하기는 하지만 주기적인 규칙성이 
없기 때문에 굳이 플리커링을 고려할 필요가 없다는 것을 의미한다. 이를 고려하여 제안 방법에서는 플리커링 수치 $D_{s c}$ 가 임계값 $T_{t h}$ 보다 크게 나타나는 경우에만 플리커링 점수를 산정한다. 또한 플리커링 점수는 식 (4)와 같이 최대 값 $T_{h i g h}$ 를 넘으면 포화된 것으로 간주한다. 본 논문에서 는 최대 점수를 5점으로 제한하였으며, 이 점수가 높을수록 플리커링 현상이 심한 경우에 해당한다.

$$
\text { Flickering Score } \text { sc }=\frac{\min \left(D_{s c}, T_{h i g h}\right)-T_{t h}}{T_{h i g h}-T_{t h}} \times 5
$$

\section{2. 플리커링 측정 실험 결과}

П장에서와 마찬가지로 다양한 실험영상에 대해 넓은 양 자화 파라미터 범위로 부호화 한 후, 프레임별 화질 변동, $v_{i}$ 을 측정하였다. 동영상 별로 약간의 차이가 있지만 플리 커링이 존재하는 경우와 존재하지 않는 경우의 대표적인 양상을 그림 5에 나타내었다. 플리커링이 존재하는 news 영상의 경우에는 I 프레임을 만날 때마다 화질 변동이 주기 적으로 튀는 현상이 뚜렷하며 양자화 파라미터 값이 커질 수록 화질 변동의 정도가 커짐을 알 수 있다. 반면에 fish

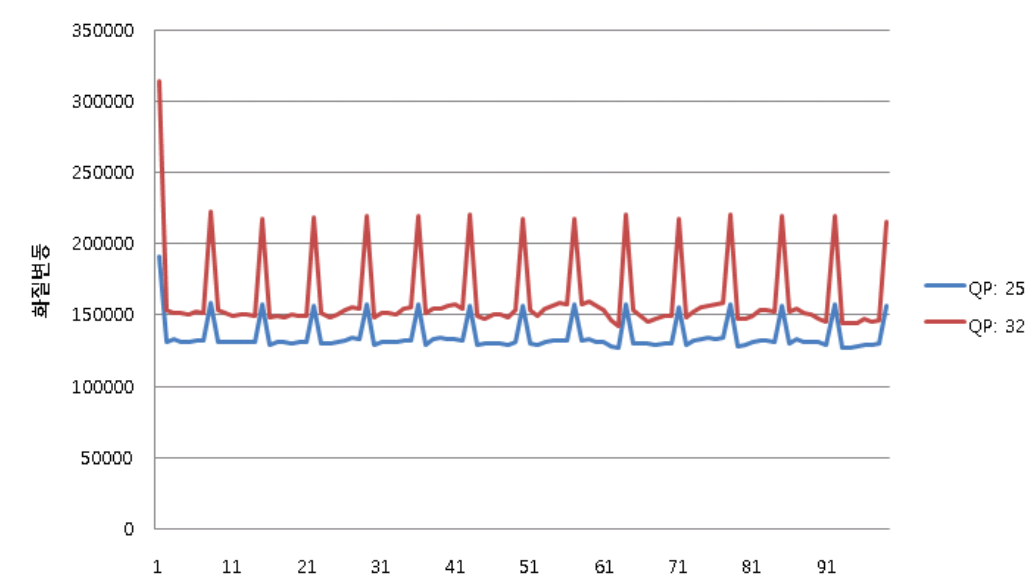

(a) News 영상의 화질 변동

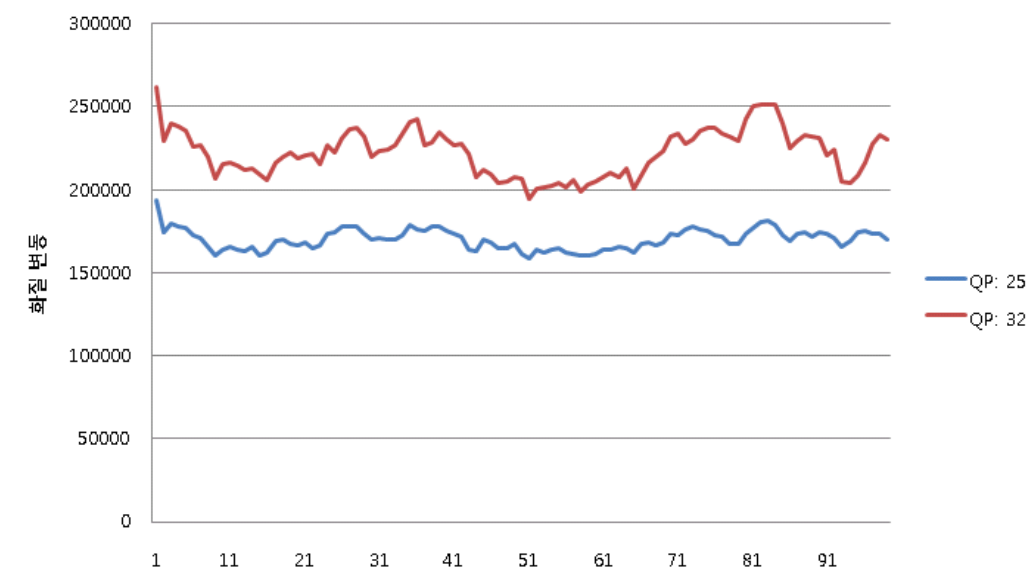

(b) Fish 영상의 화질 변동

그림 5. 플리커링 존재 여부에 따른 화질 변동

Fig. 5. Quality fluctuation according to the flickering artifact 
영상의 경우에는 양자화 파라미터 값이 커지면 화질 변동 의 정도가 커지기는 하지만 변화의 규칙성을 발견할 수 없 다. 이로부터 제안 알고리즘에서 사용하는 화질 변동의 개 념이 플리커링이라는 특징을 잘 나타낸다는 것을 알 수 있 다. 그리고 화질 변동의 절대값 보다는 상대적인 변화량이 의미가 있는 지표이기 때문에 식 (3)에서와 같이 I 프레임에 서 플리커링 수치를 계산하는 과정에서 해당 I 프레임 전후 의 $\mathrm{P}$ 프레임의 화질 변동을 고려한다.

한편 최종적으로 부호화된 동영상의 플리커링 점수를 산 정하기 위해서는 임계값을 결정하여 플리커링 구간을 설정 해야 한다. 이를 위해 실험 영상을 장면 단위로 구분하고 $\mathrm{I}$ 프레임들의 플리커링 수치 $D_{g, I}$ 와 해당 장면의 플리커링 수치 $D_{s c}$ 를 계산하였다. 그리고 양자화 파라미터를 변화시 켜가면서 장면 단위로 플리커링 수치의 변화 양상을 살펴 보았다. 예상할 수 있듯이 양자화 파라미터 값이 증가함에 따라 플리커링 수치 역시 전반적으로 증가하는 경향을 보 이는데 그림 6 에서는 양자화 파라미터 25 와 32 로 부호화한 경우에 10 개 동영상, 14 개 장면에 대한 플리커링 수치의 분 포를 나타내었다.

플리커링 수치가 0.1 보다 작게 나타나는 장면은 대부분
의 사람들이 시각적으로 플리커링을 인지하기가 쉽지 않다. 따라서 본 논문에서는 임계값으로서 $T_{t h}=0.1$ 로 설정하였 다. 피장에서 분석한 바와 같이 sport 영상과 fish 영상의 경우에는 마스킹 효과로 인해 플리커링 현상이 발견되지 않았는데, 그림에서 보듯이 이들 영상의 장면은 양자화 파 라미터가 증가함에도 불구하고 플리커링 수치가 항상 임계 값보다 작게 나타난다. 또한 mold 영상의 두 장면과 plain 영상은 양자화 파라미터가 증가함에 따라 약간의 플리커링 을 발견할 수 있고, wave 및 field 영상의 경우에 이러한 경향이 더욱 뚜렷해진다. 그리고 drama, news, weather 영 상은 양자화 파라미터가 25 에서 32 까지 변화하는 동안 전 반적으로 플리커링 현상이 나타났다. 특히 game 영상의 경 우에는 작은 크기의 객체들이 움직이고 있지만 배경은 거 의 정지되어 있기 때문에 이 영역에서 플리커링이 두드러 지게 나타나는데, 제안 알고리즘에 의한 플리커링 수치도 가장 큰 값을 보인다. 한편 대부분의 사람의 경우 $D_{s c}$ 가 0.45 보다 크면 플리커링이 뚜렷하게 눈에 띄기 때문에 본 논문에서는 $T_{h i g h}=0.45$ 로 설정하였다.

이상과 같이 임계값을 결정하면 동영상의 플리커링 점수 를 계산할 수 있다. 다음의 표에서는 플리커링 구간에 포함

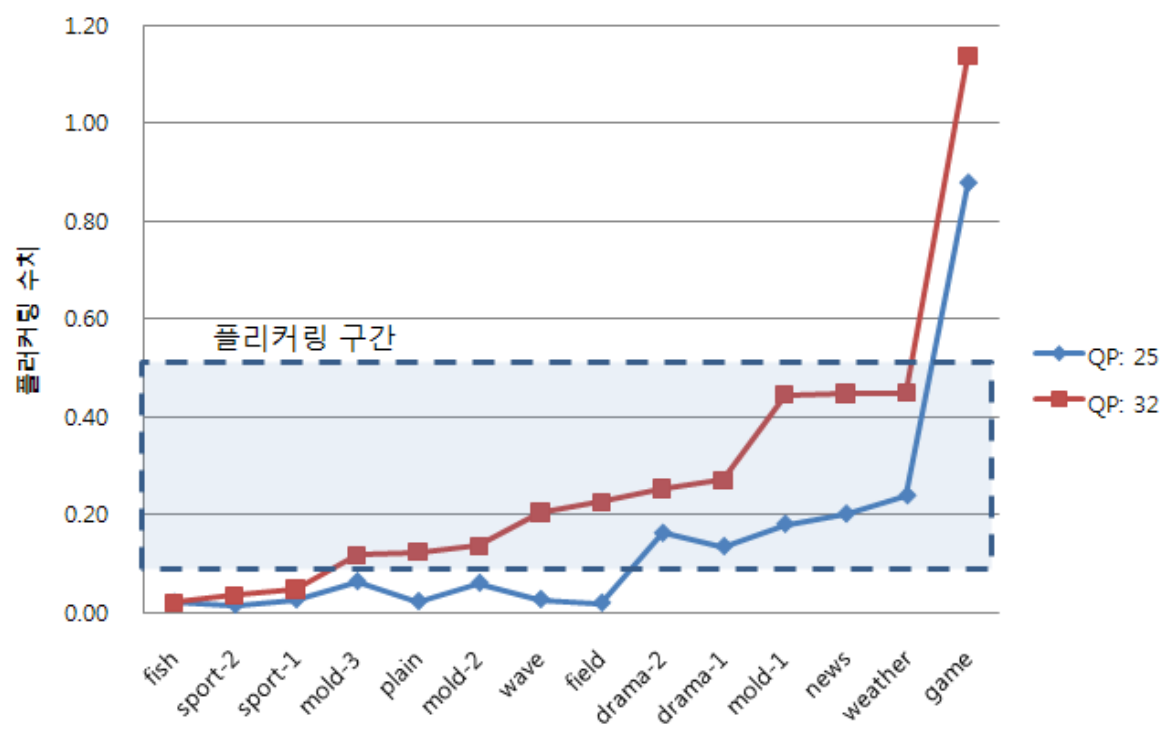

그림 6. 동영상 장면별 플리커링 수치

Fig. 6. The amount of flickering of scenes 
표 2. 실험영상에 대한 플리커링 점수

Table 1. Flickering score for the test sequence

\begin{tabular}{|c|c|c|c|c|c|c|c|}
\hline \multirow[b]{2}{*}{ 동영상 장면 } & \multirow[b]{2}{*}{ 프레임번호 } & \multicolumn{3}{|c|}{ QP : 25} & \multicolumn{3}{|c|}{ QP : 32} \\
\hline & & $D_{s c}$ & 플리커링 점수 & $\begin{array}{c}\text { ACR } \\
\text { 환산점수 }\end{array}$ & $D_{s c}$ & 플리커링 점수 & $\begin{array}{c}\text { ACR } \\
\text { 환산점수 }\end{array}$ \\
\hline field & $1-100$ & 0.02 & 0.0 & 2.5 & 0.23 & 1.6 & 4.2 \\
\hline game & $1-100$ & 0.88 & 5.0 & 5.0 & 1.14 & 5.0 & 5.0 \\
\hline mold-1 & $1-26$ & 0.18 & 1.2 & \multirow{3}{*}{3.0} & 0.44 & 4.9 & \multirow{3}{*}{3.0} \\
\hline mold-2 & $27-85$ & 0.06 & 0.0 & & 0.14 & 0.5 & \\
\hline mold-3 & $86-100$ & 0.06 & 0.0 & & 0.12 & 0.3 & \\
\hline weather & $1-100$ & 0.24 & 2.0 & 3.7 & 0.45 & .5 .0 & 4.3 \\
\hline news & $1-100$ & 0.20 & 1.5 & 2.5 & 0.45 & 4.9 & 3.8 \\
\hline plain & $1-100$ & 0.02 & 0.0 & 2.5 & 0.12 & 0.3 & 2.5 \\
\hline drama-1 & $1-56$ & 0.13 & 0.5 & \multirow{2}{*}{1.2} & 0.27 & 2.5 & \multirow{2}{*}{3.0} \\
\hline drama-2 & $57-100$ & 0.16 & 0.9 & & 0.25 & 2.2 & \\
\hline wave & $1-100$ & 0.03 & 0.0 & 5.0 & 0.20 & 1.5 & 5.0 \\
\hline sport-1 & $1-56$ & 0.03 & 0.0 & \multirow{2}{*}{0.0} & 0.05 & 0.0 & \multirow{2}{*}{0.0} \\
\hline sport-2 & $57-100$ & 0.01 & 0.0 & & 0.03 & 0.0 & \\
\hline fish & $1-100$ & 0.02 & 0.0 & 0.0 & 0.02 & 0.0 & 0.0 \\
\hline
\end{tabular}

되지 않는 경우를 제외하고 양자화 파라미터가 25 및 32 인 경우의 실험 영상의 각 장면마다 식 (4)를 사용하여 플리커 링 점수를 계산한 결과를 주관적 화질 평가 방법인 $\mathrm{ACR}$ 점수를 환산한 결과와 비교하여 나타내었다.

실험 영상 가운데 두 종류의 영상에서 제안 방법에 의한 점수가 $\mathrm{ACR}$ 환산점수에 비해 크게 낮은 결과를 보였다. 먼저 wave 영상의 경우에는 영상 내에 파도가 치는 부분과 배경인 바위 영역이 존재하는데, 파도치는 영역에서는 마 스킹 효과 때문에 플리커링이 거의 관찰되지 않지만 배경 영역에서는 확인이 된다. 배경 영역의 면적이 상대적으로 작기 때문에 제안 방법에 의한 플리커링 점수가 높지 않은 데 반해, 주관적인 평가에서는 이 영역에서의 화질 변동이 두드러지기 때문에 전체적인 점수 산정에 영향을 미친 것 으로 판단된다. 또한 plain 및 field 영상과 같이 공간적으로 세밀한 특성을 보이는 영상의 경우에도 제안 방법이 주관 적인 평가 결과 보다 낮게 나타난다. 그러나 전반적으로 대 부분의 영상의 경우 넓은 화질 범위에서 제안 방법에 의한 점수가 사람의 시각적인 인지 특성과 양의 상관관계를 나 타냄을 알 수 있었다.

\section{IV. 결 론}

멀티미디어 동영상의 부호화 과정에서 발생하는 플리커 링 현상은 대표적인 시간적 잡음으로서 IPTV 및 DMB 서 비스의 품질 평가와 관련하여 중요성이 강조되고 있다. 본 논문에서는 주기적으로 I 프레임이 삽입되는 GOP 구조를 사용하는 부호화 환경에서 플리커링 현상이 발생하는 원인 을 분석하고, 동영상의 공간적 특성 및 시간적 특성에 따라 인간이 시각적으로 인지하는 플리커링 현상의 마스킹 효과 에 대해서 살펴보았다. 플리커링 현상은 부호화된 영상의 화질이 너무 좋거나 너무 나쁘지 않은 중간 영역에서 중요 하게 고려해야 할 부호화 잡음이며, 프레임 내의 공간적 세 밀함의 정도, 객체의 크기, 움직임의 정도, 카메라 파라미터 등에 따라 영향을 받는다. 이 현상은 일반적으로 움직임 영 역보다는 정지 영역에서, 복잡한 영역보다는 단순한 영역 에서 두드러지는 경향이 있으며, 동영상 내에 움직임이 활 발한 큰 객체가 있는 경우에는 눈에 잘 띄지 않는다.

또한 본 논문에서는 플리커링을 부호화된 동영상 화질의 시간적인 변동으로 정의하고 이를 객관적으로 평가하는 도 
구를 개발하기 위해 FR 기반의 측정 알고리즘을 제안하였 다. 다양한 특성을 가지는 여러 동영상을 대상으로 플리커 링 평가 실험을 수행하였으며, 양자화 파라미터를 변화시 켜가면서 얻은 넓은 화질 범위에서의 실험 결과를 통해 제 안 알고리즘에서 사용한 화질 변동이 플리커링을 잘 나타 내는 특징이 된다는 사실과 이를 바탕으로 계산한 플리커 링 수치가 사람의 인지적 시각 특성과 잘 부합됨을 확인하 였다.

\section{참 고 문 헌}

[1] 정경훈 외 '멀티미디어 방송 서비스를 위한 $\mathrm{QoS} / \mathrm{QoE}$ 평가 기준 및 방 법 연구, 방송통신위원회, 2008년.

[2] Becker, A, Chan, W. Poulouin, D. 'Flicker reduction in intraframe codecs', Proceedings of Data Compression Conference, pp.252-261, 2004.

[3] A. Leontaris, Y. Tonomura, and T. Nakachi "Rate control for flicker artifact suppression in motion JPEG2000," Proceedings of
Acoustics, Speech and Signal Processing, vol. 2, pp.41-44, May 2006.

[4] X. Fan, W. Gao, Y. Lu, and D. Zhao, "Flickering reduction in all Intra frame coding", JVT-E070, Joint Video Team of ISO/IEC MPEG \& ITU-T VCEG Meeting, Oct. 2002.

[5] S. Sakaida, K. Iguchi, S. Gohshi, and Y. Fujita, "Adaptive quantization control for reducing flicker of AVC/H.264 intra frames," in Proc. Picture Coding Symposium, Dec. 2004.

[6] S. S. Chun, H.-J. Ryu, and S. Sull, "Flicker reduction in Intra coded frames of H.264/AVC", Proceedings of International Conference on Image Processing, pp.2025-2028, Oct. 2006.

[7] K. Chono, Y. Senda, and Y. Miyamoto, "Detented quantization suppress flicker artifacts in periodically inserted Intra-coded pictures in H.264 video coding", Proceedings of International Conference on Image Processing, pp.1713-1716, Oct. 2006.

[8] Hua Yang, Jill M. Boyce, and Alan Stein, "Effective flicker removal from periodic intra frames and accurate flicker measurement," Proceedings of International Conference on Image Processing, pp.2868-2871, Oct. 2008.

[9] JVT Reference Software : http://iphome.hhi.de/suehring/tml/

[10] ITU-T P.910 'Subjective Video Quality Assessment Methods For Multimedia Application'

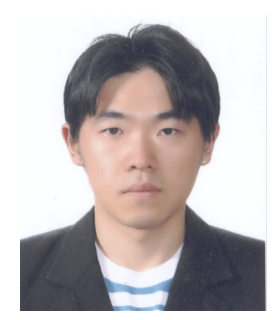

\section{임 종 민}

- 2008년 2월 : 국민대학교 신소재공학부 학사

- 2010년 2월 : 국민대학교 대학원 전자공학과 석사

- 현재 : (주) 코셈 연구원

- 주관심분야 : 영상신호처리, 화질평가 및 개선

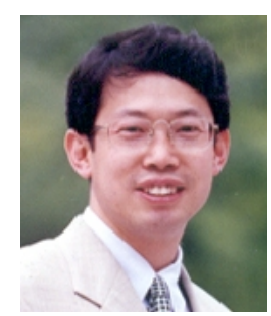

\section{강 동 욱}

- 1986년 2월 : 서울대학교 전자공학 졸업

- 1988년 2월 : 서울대학교 대학원 전자공학과 석사

- 1995년 2월 : 서울대학교 대학원 전자공학과 박사

- 1995년 현재 : 국민대학교 전자공학부 교수

- 2000년 9월 2001년 8월 : Lucent Technology MTS

- 주관심분야 : 비디오 코딩, 영상통신 
저 자 소 개

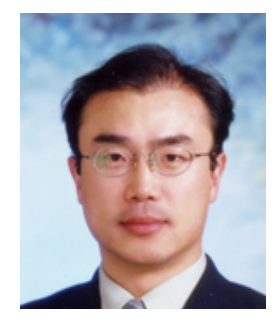

정 경 훈

- 1987년 2월 : 서울대학교 전자공학 졸업

- 1989년 2월 : 서울대학교 대학원 전자공학과 석사

- 1996년 2월 : 서울대학교 대학원 전자공학과 박사

- 1991년 12월 1997년 2월 : 한국영상산업진흥원 선임연구원

- 1997년 3월 2005년 2월 : 한동대학교 전산전지공학부 교수

- 2005년 3월 현재 : 국민대학교 전자공학부 교수

- 주관심분야 : 멀티미디어신호처리, 디지털 방송 